\title{
From Racial Democracy to Credit Democracy: Finance and Public Security in Brazil
}

Brian Whitener

--You said before that you didn't steal anything, you just “carried a few things home." But if you take something that isn't yours, isn't that stealing?

--Well, those things weren't exactly mine, no. But let me tell you something. About a year ago when that store opened, everyone in the neighborhood bought stuff-on the "easy credit plan," they called it. I bought a blender because my wife wanted one real bad. She'd seen some ads and really liked them. I also bought a TV so we could have a little entertainment at home. And then comes this problem of the bad unemployment we're in. I still got no job. So, anyway, I missed two monthly payments and I went down there to explain why. But they didn't want to hear about it, they came and took the television and the blender and everything. And they didn't even give back the eight payments I made. No job and no TV. So I figured they owed me something, and I was just being, like, compensated. But I only took what I thought was fair. (Ignácio de Loyola Brandão, Zero p. 161)

The so-called "new middle class" of Brazil has been the object of countless studies and homages-perhaps to the point of exhaustion. They have been called the new batalhadores, seen as a new source of wealth "at the bottom of the pyramid," and heralded as the protagonists of a new era of Brazilian politics. However, what went overlooked or under-analyzed, for many years, in these paeans and pesquisas, is perhaps 
today finally coming to the surface: namely, the centrality of credit-which is not a wage but rather money one has to pay back and with interest - in this Brazilian "miracle" and the state's role in providing it. What was lost amongst the celebrations of "sustainable development" and upward class mobility is that since 2003 Brazil has witnessed a massive expansion of personal credit, across almost all sectors of society. With the slowing of GDP growth, starting in 2012, and after the popular uprisings in June 2013, there is more space now for critical approaches to this most recent boom and for questioning the role of the state in producing a situation in which as of July $201521.5 \%$ of families are behind on one credit account (CNC 2015) and where the APR on some credit cards has hit 345\% and APRs of at least 200\% are common (Martello 2015). ${ }^{1}$

While real wages most certainly did rise in the period after 2003, the expansion of credit has been just as strong. ${ }^{2}$ Since 2003 , the total amount of credit to pessoas físicas has grown from $\mathrm{R} \$$ 84,792 milhões to 789,428 milhões as of May 2015 (Banco Central 2003; Banco Central 2015a). ${ }^{3}$ Total credit to households as a percentage of GDP (a common rule of thumb for measuring the amount of consumer credit) is hovering around $46 \%$, having grown from 18\% just a decade ago (Banco Central n.d.; The Economist 2015). Most importantly, currently debt service takes up roughly $22 \%$ of all disposable income in Brazil (Banco Central 2015b: 22; Banco Central n.d.). For comparison purposes, debt service in the United States is equal to $9.92 \%$ of income and, in the months before the

\footnotetext{
${ }^{1}$ For example, a featured interview in the December 2014 issue of the Brazilian credit industry's trade journal Credit Performance with political scientist Murillo de Aragão is framed by his declaration, "A expansão do crédito para alavancar o crescimento econômico parece ter chegado ao limite" (Balthazar 9). Through the first six months of 2015, 93 Brazilian companies have had their credit ratings downgraded and U.S. investment banks are now investing in Brazilian debt collection agencies in anticipation of increasing defaults (Levin 2015; Pacheco 2015).

${ }^{2}$ Between 2002 and 2013 the minimum wage in Brazil increased from R\$ 200,00 to R\$ 678,00, an increase of 70.49\% (Vozes 2013: 19).

${ }^{3}$ The Banco Central do Brasil divides its reporting of credit to individuals (pessoas fisicas) into two categories: "recursos livres," which includes such things as crédito consignado, credit cards, cheque especial, and auto loans and "recursos direcionados" which include housing, BNDES, and rural development loans. The numbers above refer to the total amounts of lending in the "recursos livres" category.
}

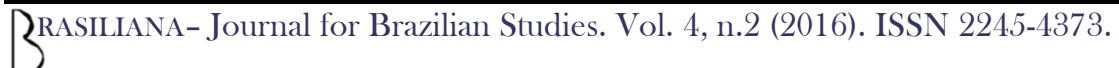


2008 financial crisis, broke 13\% for the first time since the Federal Reserve began tracking these numbers in 1980 (Federal Reserve 2015). What this means in practical terms is millions of people all over Brazil paying massive amounts of interest for homes full of appliances, for new or used cars, and, increasingly, for their homes themselves. However, credit has been sold by the governments of the Partido dos Trabalhadores (PT) as a part of a process of "democratization," of making society more "inclusive," and while it may change consumption patterns, mass credit has most certainly made a great deal of money for those holding the loans (which includes a broad selection of national and foreign elites, as well as state banks). The rapid expansion of mass credit during the Lula and Dilma administrations, and its effects on social and cultural life, then, remains an under-researched question (Müller 2014).

In this article, I examine the social effects of this credit expansion by positioning credit as a form of public security. In the first part of this article, I chart the expansion of personal credit as a form of financial corporativism during the PT governments in Brazil since 2003. As well, I trace some of the principle cultural mediations of credit and the role of Rio de Janeiro as the site of the production of these mediations, in particular the transition from discourses of racial democracy to credit democracy elaborated in the 2012 novela Cheias de Charme. In the second part, I turn my attention to the kind of subjects that credit expansion has produced. Here I argue that credit expansion has produced a form of the subject as a pass-thru or gateway in which the state is less concerned with subjects' interiority and more with facilitating the seizure of assets. This seizure requires a concomitant expansion of militarization and the threat of state violence which further hollows out the subject. I conclude by returning to Rio de Janeiro to apply these insights to the post-UPP political environment. My overall argument is that credit has functioned as a form of or has impacted public security in two ways: first, state-linked discourse and cultural productions concerning credit-based consumption 
have produced new figures of national belonging, while, second, the legal environment required for credit expansion produces subjects increasingly exposed to the threat of state violence.

\section{Crédito Consignado: Mass Credit and Corporativism}

In the process of financial liberalization in the 1990s, many Latin American countries privatized, to various degrees, their banking systems. What differentiates Brazil is the degree of public control maintained via the government's direct and indirect control of large pension funds (Jardim 2007), as well as public banks such as Caixa and Banco do Brasil and the development bank, BNDES. These forms of government control over public money have made possible the attempted reorientation of the Brazilian economy around internal demand supported by mass consumer credit (as well primary commodity exports to China). Due to its control of these large state banks and other financial levers, the federal government can incentivize or prime the amount of personal credit in the market. However, under the Lula administration, the state went one step further, in essence creating a "new" form of personal credit, known as crédito consignado. ${ }^{4}$ While all forms of personal credit can be thought of in some way as enacting a kind of financial corporativism (as the state ultimately can regulate how much credit is being offered by lenders and the state controls the legal environment defining different credit modalities), crédito consignado represents a more direct form

\footnotetext{
${ }^{4}$ The legal framework for payroll lending had existed since the 1930s and BMG had been making consignado loans to governmental employees since the late 1990s (Ferreira 2006: 8).
} 
and a discussion of the rise of this credit modality sheds light on how financial corporativism has worked in general during the recent PT administrations. ${ }^{5}$

One of the key instruments that have made possible the expansion of consumer credit was the massification of a formerly little used modality of credit, crédito consignado, which occurred in 2003-2004. Crédito consignado functions essentially as a payroll deduction loan, which means that as long as someone is employed in the formal economy or is receiving their retirement benefits, their loan payment is deducted directly from their paycheck or benefits payment. As such, the loans carry very little risk; in particular loans to retirees are almost risk-free. As of May 2015, crédito consignado accounted for roughly 33\% of all credit to individuals (including auto loans) and since 2005 the amount of consignado loans has increased 382\% to total, as of May 2015, R\$ 263 bilhões (Banco Central 2015a; Oliveira 2015).

The creation of crédito consignado forms a part of a larger story of what Roberto Grün has termed the "financeirização de esquerda" and Ricardo Antunes "sindicalismo de negócio" (Antunes 2004; Grün 2009). As Grün notes, Central Única dos Trabalhadores [CUT] and Força Sindical had, in the 1990s, begun to fight for control of or influence over large pension funds (Grün 2004; Grün 2005). By 2003, these large union federations, in particular CUT, which has close ties to the PT, began undertaking negotiations that would allow them to offer consignado to union members (Moreira 2005: A4). While the rhetoric of the unions was of attacking banks (i.e., negotiating lower interest rates for members), in fact the unions were contesting with the banks for financial service revenue streams (Weissheimer 2004). When in November of 2003, CUT

\footnotetext{
${ }^{5}$ In addition, a large portion of all credit to individuals has been provided by state-owned banks, and their share of lending is increasing, from 35\% of all loans in 2009 to 55\% in 2015 (Associated Press 2015). As well, instead of reading the recent past in Brazil has part of a "transition to democracy," my approach emphasizes rather the carryover of corporativist and state policing structures and the tendency to secure state control through their capillary extension and amplification (Wiarda 2004; Zaverucha 2005).
}

RRASILIANA- Journal for Brazilian Studies. Vol. 4, n.2 (2016). ISSN 2245-4373. 
signed a deal creating a crédito consignado structure for some of its members, Lula's finance minister, Antonio Palocci was present at the signing, highlighting the degree of government support in preparing and promoting the new credit form (Moreira 2005: A4).

In September 2004, the Lula government extended crédito consignado to individuals with INSS benefits, in effect massifying the consignado credit structure beyond the PT union-linked base (Salomon 2006; Gigliucci 2011). The lower interest rates led to the quick expansion of consignado to INSS recipients and the slow extension of consignado from public to some private workers. In practice, the consignado loans function like a line of credit. The INSS, for example, sets a cap on the amount that can be lent from an individual's benefit payment (currently 30\%). ${ }^{6}$ If a retiree gets a monthly benefit payment of $\mathrm{R} \$ 1000$, they can have up to $\mathrm{R} \$ 300$ per month deducted directly from their payment. This $\mathrm{R} \$ 300$ functions like a line of credit which the retiree can use to make commodity purchases or put towards a payment on a car or even house loan. Many consignado providers also offer credit cards, allowing part of the credit to be used through this modality.

Crédito consignado was from the very start a government-linked program and part of an attempt to promote domestic consumption after the recession of the early 2000s. ${ }^{7}$ Lula's finance minister Antonio Palocci declared in 2003 that he expected R\$ 20160bn in consignado loans to be made, and when it became apparent that this wasn't happening, public banks began to buy the loan portfolios of smaller banks like BMG (Banco de Minas Gerais) who were making the majority of consignado loans (this

\footnotetext{
${ }^{6}$ On July 7, 2015 the government raised the limit from 30 to $35 \%$ but this extra $5 \%$ can only be used for paying down credit cards. In essence the limit which can be used for new debt continues to be $30 \%$.

${ }^{7}$ Credit provision has been an important part of the recent boom, as 50\% of GDP growth seen in the last ten years has come from private consumption (The Economist 2015).
}

3RASILIANA- Journal for Brazilian Studies. Vol. 4, n.2 (2016). ISSN 2245-4373. 
functioned like a form of securitization, allowing the banks to make more loans; Rodrigues 2003; Nascimento 2008; Ferreira, Leitão and Sadi 2012). While much has been written about the Bolsa Familia as a wealth redistribution program, it amounts to only 0.05\% of GDP per year (Watts 2013). Accumulated domestic credit in Brazil, as noted before, stands at roughly 55\% of GDP. Credit then has been the PT government's most important strategy of attempted "wealth transfer"; the question is in what direction is the wealth really flowing, as even with 21-32\% APR (current rates for consignado loans for public employees [Banco Central 2015c]) many consignado borrowers can end up, depending on the length of the loan, paying back almost double, or more, of what they have borrowed and none, as long as they are employed in the formal labor market (for active workers) or are alive (for retirees), have the ability to stop, skip, or renounce payments.

The 1980s and 1990s witnessed a widening gap between the formal and informal labor markets and the increasing inability of the state to mediate the capital-labor relation through traditional corporativist structures (Bensusán and von Bülow 1998; Boito Jr. 1999; Veloso 2012). The movement of the PT as the party of labor into control of pension funds and the movement of unions themselves into financial services was an early reformulation of these corporativist structures. The central instruments of mass credit, such as crédito consignado, are developed from within and by union structures and then taken over by social security and the private sector. Thus, the expansion of personal credit should be seen, along with the expansion of state police and paramilitary forces in the same period, as a structure that emerges to reestablish a form of social control beyond the processes of production, outside the traditional form of capital-labor mediation through the wage- which is not to say this traditional form of mediation has entirely disappeared, rather it has been supplemented by credit and state violence. The fact that state violence and credit as non-traditional corporativist structures emerge at 
the same time is important because the utopian promise of credit, the "equality" through consumption it promises, is highly unstable and primarily illusory. Thus, as we will see, not only is the utopia of credit one that leaves critical social relations, particularly those of social reproduction, untouched, it also requires and calls forth new forms of state violence once its shaky promises begin to fail. ${ }^{8}$

\section{A Nova Classe Média (Parcelada)}

The debate over the social effects induced by the rise of credit in Brazil has played out through the discursive construction and contestation over a category that has been labeled, "a nova classe média." While both real wages and state income transfers have grown since 2003, the key documents which have produced and promoted the category of the new middle class - regardless of the problems with their definition of classdepend, in ways that generally have not been foregrounded, on the expansion of credit. ${ }^{9}$ I start here in order to deconstruct this category that has received a wide projection and to demonstrate its dependence on credit expansion. While traditional approaches to the definition of economic classes are based in income, social status, or location in the relations of production, discursive constructions of the new middle class have centered

\footnotetext{
${ }^{8}$ Initially, mass credit is tipped in favor of union employees, which functions as a reinforcement of Brazil's labor aristocracy (in the Bakunin sense), but this does not last for long. While crédito consignado is never formally extended to those in the informal sector, informal workers have access to credit through retail stores and through the practice of lending credit cards to friends or family members to make purchases.

${ }^{9} \mathrm{I}$ am bracketing here a larger debate about the definition of class in these works on the nova classe média, in particular the Bourdieusian and Marxist critiques they have received. For example, Brazilian sociologist Jessé Souza in Os Batalhadores (2012) argues, from position informed by Bourdieu, that definitions of the "nova classe média" that focus on power of consumption are economistic and as such miss the crucial spectrum of symbolic and cultural capital. Philosopher Marilena Chaui (2013) has argued, in a series of talks that have circulated widely in the Brazilian blogosphere, for a more traditionally Marxist definition of the middle class as defined by their position in the relations of production (see also Pochmann 2014). My argument with the Bourdieusian and classical Marxist positions is that they also push into the background the credit expansion, thus rendering it as invisible as in the economistic approaches.
}

RRASILIANA- Journal for Brazilian Studies. Vol. 4, n.2 (2016). ISSN 2245-4373. 
on, or made space for, not only income, but the kinds of objects in a home. Thus, the idea of a new middle class has been at least partially defined-frequently without being explicitly stated-by what can be purchased with credit. It is this association of the new middle class with consumption tout court (occurring by wages or borrowed funds) which has carried over into the journalistic media and popular consciousness and has led to the creation of a new cultural imaginary of credit democracy.

The category of the "nova classe média" was advanced in key ways by two documents. The first was a classificatory system which began to be used by the Associação Brasileira de Empresas de Pesquisa (ABEP) and which was developed in the late 1990s (ABEP pers. comm.), known as the Critério de Classificação Econômica Brasil (CCEB) or, simply, the Critério Brasil. The Critério abandonded "a pretensão de classificar a população em termos de 'classes sociais,'” that is through income (Associação 2003). Instead the Critério builds classes (into the standard Brazilian system of A-E) through a point system based on consumer objects in the home and the level of education of the "chefe de familia." Here the hidden dependence on credit in the definition of the new middle class is clear as both consumer items, and frequently education, depend on the provision of credit for purchase.

The second document, Marcelo Neri's 2010 A Nova Classe Média: O Lado Brilhante dos Pobres (published by the prestigious Fundação Getulio Vargas), created a classificatory system based on income in which $50.9 \%$ of the population had become by 2009 classe C, or "middle class." However, it also gave, if not analytic weight, then descriptive space to the ABEP approach of thinking of class as a function of the power of consumption (Neri 2010: 52 passim). While Neri's approach is based in income, it also makes room for the Critério association of class with the power of consumption.

What is important is how in the Critério, Neri's work, and the flood of popular press and journal articles that followed the publication of A Nova Classe Média, this new 
power of consumption defines a new national subject - the new middle class or classe C which now encompasses over half the population. As Neri writes, classe C "é a imagem mais próxima da sociedade brasileira" (5). The literature on the nova classe média, in its academic, business, and popular flavors, produces a new national subject, one not just of production (of labor, the wage, and the worker), but of finance and consumption, and, more specifically, of credit. The discursive framing of equality through consumption, which is then amplified in various mass cultural products, define a new national imaginary, not of racial democracy, but rather of what we might call "credit democracy."

\section{Credit Democracy and Cheias de Charme}

During the 1930s and 40s, the Vargas dictatorship, like many Latin American states at the time, incorporated a theory of mestizagem into the formation of a national popular culture (Alberto 2011: 9-11; Telles 2014: 177-180). While the Vargas state incorporated elements of Afro-Brazilian culture (samba, carnival, futebol, malandragem) into the foundation of Brazilian national culture, intellectuals elaborated a theory of "racial democracy," which celebrated Brazil as a country without, or with minimal, racial discrimination. Peripheral urban areas (in particular those of Rio de Janeiro, then the national capital) occupied a contradictory place in national popular culture: as sites of racialized proletarian exclusion but also as the cradle of national culture. This system of national integration via a "racially democratic" national culture began to break down in the 1980s and 90s for two reasons. First, the 1982 debt crisis, hyperinflation, and the implementation of neoliberal reforms meant that the Brazilian state put fewer resources into the corporativist structures which had underpinned this imaginary. Second, starting in the military dictatorship, militant black intellectuals began to question the 
myth of racial democracy, arguing that it was more a technique of social control used to mystify and pacify peripheral populations than an ideal that the Brazilian state was committed to realizing (Alberto 2011: 17).

With the "stabilization" of the Brazilian economy in the 2000s and the coming to power of the PT, the state began to rebuild its corporativist machinery of which, as we have seen, the provision of credit was an important part. In the discourses around the nova classe média we can see the beginnings of a new collective imaginary, used to fuse individuals into the nation. The imaginary that has been produced has not been a return to racial democracy, but rather what we might call credit democracy. While government-linked discourses around the nova classe média begin this process of articulation, it is in mass cultural production where the new subject positions and horizons of this formation have been fashioned and disseminated nationally. ${ }^{10}$ These cultural productions, much like the national cultural productions of the Vargas period, are overwhelmingly set in Rio de Janeiro, which continues to serve as the backdrop for the creation of national cultural imaginaries. In the following, I discuss one such production, the 2012 novela Cheias de Charme and its crafting of a form of credit democracy. If racial democracy was concerned with producing forms of cultural commonsense that obscured real structures of racial and class domination, the imaginary of credit democracy posits a false equality of consumption which obscures, as well, very real differences in access to goods and services as well as forms of race and class inequality that cannot be overcome by credit-based consumption. At the same time, Cheias reveals the imaginary of credit democracy to be an internally fragile one, as

\footnotetext{
${ }^{10}$ This is part of a larger recalibration of the state's approach to race in this period; see Reiter and Mitchell (2010) for a window into this new environment and Joseph (2013) for a summary of the different positions in current debates on racial democracy in Brazil. As should be clear, I think there has been an important shift away from the discursive nexus of racial democracy.
} 
the dreams of social accession in the novela itself cannot be realized through increasing wages or credit but rather require the deus ex machina of pop stardom.

Cheias de charme tells the story of three women-Maria da Penha (Taís Araújo), Maria Aparecida (Isabelle Drummond) and Maria do Rosario (Leandra Leal)employed as domestic workers, who form a music group "As Empreguetes" and become an overnight sensation. Cheias, a Globo novela, was on the air from April 16, 2012 to September 28, 2012 and while not the most successful Globo novela of the moment (that would be Avenida Brasil), its narrative of lower class upward mobility became a frequently cited point of reference for the changes in and debates over the new Brazilian "middle class" (Mauro and Trindade 2012; Grijó 2014). However, Cheias, more than Avenida, articulates the presumptions and horizon of credit democracy, in part because its plot turns around the very notion of equality and the overcoming of differences between social classes. In the novela, the lives of the three Marias are turned upside down after their self-recorded song (and video) go viral. Their accession to pop stardom makes them into the social equals of their former bosses and enables them to enact all their fantasies of consumption-during the novela they buy houses, reform them, and fill them with electrodomésticos. ${ }^{11}$ The show then does not specifically focus on credit, but rather on the credit-form or the fantasy of equality via credit-based consumption. That is, credit exists in the background, occasionally appearing in moments of consumption, while the show itself models the fantasy of credit-enabled consumption, namely the ability to transcend or suspend one's socio-economic position. This mix of the belief in potential equality through consumption and the obscuring of structural class and race difference through their (temporary) suspension is what defines the cultural imaginary of credit democracy.

\footnotetext{
${ }^{11}$ In one episode (\#79), Penha buys a new car (a Volkswagen) and cooks dinner uses her new kitchen while Cida dines in the same restaurant as her former employers, much to their disgust.
} 
Cheias is a form of Latin American telenovela which has become very popular and lucrative in recent years. By making novelas that center on fictional pop groups (the Argentinean novela Rebelde Way was among the first in this genre), media companies have been able to add additional revenue streams, including CD and single sales of the songs made popular on the show, concert tickets, etc. While the show itself was popular, part of its wide cultural dissemination was its utilization of multiple media platforms, including the singles spun off from the show and contests in which domestic workers were invited to submit their own videos with a chance to win a guest appearance on the show. In Cheias, the first single from the group, "Vida de empreguete," condensed a series of cultural concerns, perceptions, and aspirations over the new middle class and credit expansion - which can be seen in part by the number of parodies and remakes the single has received in different cultural mediums, in particular on the internet video site Youtube. This single mixes references to credit-enabled consumption with class-based revenge fantasies against cruel mistresses and their vain, ungrateful offspring. In short, the song mixes affects resulting from structural positioning with the aspirational content of this positioning's suspension:

Todo dia acordo cedo

Moro longe do emprego

Quando volto do serviço quero meu sofá

Tá sempre cheia a condução

Eu passo pano encero o chão

A outra vê defeito até onde não há

Queria ver a madame aqui no meu lugar

Eu ia rir de me acabar

Só vendo a patroinha aqui no meu lugar 
Botando a roupa pra quarar

Minha colega quis botar

Aplique no cabelo dela

Gastou um extra que era da parcela

As filhas da patroa

A nojenta e a entojada

Só sabem explorar, não valem nada

$\cdots$

Levo vida de empreguete, eu pego às sete

Fim de semana é salto alto e ver no que vai dar

Um dia compro apartamento viro socialite

Toda boa, vou com meu ficante viajar

Cheias and the song "Vida" draw on academic and journalistic accounts' framing of the rise of the nova classe média as a narrative of the production of equality through consumption. In the single, this equality ("compro apartamento") is linked to the suspension of the domestics' structural positioning ("um dia"). In the case of "Vida," this positioning is determined by the division of labor of social reproduction, of who does the dirty work of "passando pano" and "botando a roupa" under the arbitrary power of others. ${ }^{12}$ However, credit-enabled consumption ("da parcela") cannot realize in a tangible way all the desires forwarded by the song "Vida," and thus the only way to make good on credit and consumption's promises of equality is through the external device of pop music stardom. That is, even the narrative universe of Cheias appears to lack faith in credit's ability to change structural conditions. This, then, is the

\footnotetext{
${ }^{12}$ One thing that cannot be paid for with credit is wages. Thus, of all of the changes in Brazilian households in this period, one thing that does not change drastically is the composition of the labor of social reproduction.
} 
contradictory imaginary offered by credit democracy: the belief in the possible suspension of one's positioning in a certain set of social relations (or the belief in equality through consumption) accompanied by the suspicion that this suspension will only be temporary or might be impossible.

There is a tendency for cultural objects in a moment of credit (such as Cheias and news reports on the "nova classe média") to focus on those individuals whose positioning is most disadvantaged within the division of labor. Maids, cooks, and sex workers all attract attention in this moment as subjects of economic and journalistic reports: why? I would argue this is because credit promises equality but is, in fact, most adapt at delivering the temporary suspension of one's socio-economic location. Thus, the concern with figures positioned at the very low end or in the most socially degraded parts of the division of labor is driven by the impact of the suspension that can be realized there. Maids buying sofas; maids buying houses - the sudden traversal of this distance in consumptive power is a kind of sublime equality effect of credit and generates a good deal of the affective impact of Cheias as well as of journalistic puff pieces that push the (false) equality of consumption. Moreover, in Cheias this equality effect of the credit-form affects an erasure of race: domestics in São Paulo and Rio de Janeiro are predominantly women from Afro-Brazilian backgrounds, while in Cheias only one is visibly marked as Afro-Brazilian (Taís). In this way, the form of credit democracy produced in Cheias has the added effect of making race almost completely disappear as a problematic of Brazilian society.

The aspirational form of credit which underpins the imaginary of credit democracy presents itself as inheriting a prior socialist or social democratic imaginary of the wage as a mechanism for the redistribution of surplus. The promise of wage redistribution was not necessarily the promise of a structural change in or overthrowing of the relations of production, but it was most definitely a redistribution of wealth. 
Credit cannot fulfill either a function of redistribution or structural change; it can rather only deliver a temporary equality in (certain) patterns of consumption. Clearly equal consumption of refrigerators or airline tickets does not mean equal income, equal rights, or equal access to more prestigious or valuable goods (e.g., homes, education, pensions, state services or protections). However, contemporary discussions of credit in Brazil appropriate the aspirational language of previous left movements for the ends of sculpting a new national imaginary: credit is a net positive in these accounts, because it democratizes consumption and creates a more "inclusive" society. While for many years the dominant discourse of consumption (via credit) was as a form of equality or democratization, its reality, which is perhaps more tangible now, is that it is a site of extended financial exploitation.

While the state has controlled the spread of credit and the production of an environment in which consumption has been sold as a new form of equality, the state does not get to chose how this environment comes to be mediated culturally - though it has tried to influence this as much as possible. Through its promotion of discourses of the nova classe média, the PT state has attempted to control the framing of credit expansion as a net positive; as we can see in Cheias, however, the cultural imaginary of credit and consumption has come with suspicion built into it. To the extent that statepromoted ideologies, such as racial democracy, attempt to suture real differences of race and class, such formations have always been in contradiction with the structural conditions out of which they were developed. The difference between racial democracy and the kind of credit democracy or promise of equality through credit-enabled consumption seen in Cheias is that the latter is a discursive form that appears to not entirely believe in itself.

3RASILIANA- Journal for Brazilian Studies. Vol. 4, n.2 (2016). ISSN 2245-4373. 


\section{The Anti-Subjects of Credit}

Financial corporativism not only produces figures of the nation but works on the level of the subject as well. In Discipline and Punish, Foucault discusses modern disciplinary procedures as producing the "modern soul" (23). With the rise of disciplinary apparatuses and institutions of enclosure, disciplinary techniques like imprisonment came to reform the soul instead of punishing the body. They did so, however, through a complex set of processes aimed at the body; which Foucault describes as the art of distributions (placing bodies in enclosed, portioned spaces), the control of activity (of time and gesture), the organization of "geneses" (various forms of training), and the composition of forces (tactically combining individual bodies into larger "machines"). All these are operations on a body, but ones which give rise to the subject's interiority, its "soul."13

If the subject as we have known it since the seventeenth century has been created by "subject[ion] to someone else by control and dependence" and through the production of "a conscience or self-knowledge" (Foucault 1982: 781), the specific environment of credit expansion has required a shift in this apparatus, from a concern with monitoring the interiority of individuals to turning the subject into a pass-thru or gateway to an asset. That is, in the moment of personal credit, the state has become less concerned with the "souls" or interiority of individuals and has instead prepared a legal environment in which the subject serves as a gateway for repossessing or seizing assets and income. As we will see below, this legal environment, which exposes individuals to

\footnotetext{
${ }^{13}$ Foucault writes: "It would be wrong to say that the soul is an illusion, or an ideological effect. On the contrary, it exists, it has a reality, it is produced permanently around, on, without the body by the functioning of a power that is exercised on those punished - and, in a more general way, on those one supervises, trains and corrects. This is the historical reality of this soul, which, unlike the soul represented by Christian theology, is not born in sin and subject to punishment, but is born rather out of methods of punishment, supervision and constraint" (29).
} 
state violence in new ways, was a necessary requirement for the expansion of personal credit in Brazil.

This approach to the subject and credit differs from what has been so far the most in-depth work on the relation between the subject and finance (in this case, debt), Maurizio Lazzarato's The Making of the Indebted Man (2012), which tracks the asymmetry of power inherent in debt. Drawing on a rich philosophical tradition of thinking on debt (including Nietzsche, Marx, and Deleuze and Guattari), Lazzarato makes an argument for debt and debtor-creditor relationships as the "archetype of social relations." For Lazzarato, making debt the archetype of social relations means society is based in "an asymmetry of power and not on that of a commercial exchange that implies and presupposes equality" (33). Debt implies the production of a subject who secularizes Christian guilt, promising to repay and to keep his or her promises (164).

My position is that credit, in general, but also specifically in the way it has been massified in Brazil, represents less a social relation of obligation and more a new commitment on the part of the state to use or allow violence to seize assets and to defend a narrower definition of property and collateral. That is, credit is not merely a social relation but requires a new social environment, one which blends very specific legal characteristics and public security institutions and apparatuses. To "convince" banks to lend to individuals has required giving them the ability, authority, and means to repossess whatever the credit was used to purchase, to seize future income, and/or the assets posted as collateral. In short, credit requires the readying of a legal environment where repossession is swift and difficult to contest and in which the state or parastate forces signal their readiness to do or support the work of repossession and to defend intensified notions of private property. In this way, credit represents an important site of imbrication between the militarized security state and the financial corporativist state. This legal environment, due to new linkages between repressive and 
institutional state apparatuses, produces, not subjects with "modern souls," but rather subjects whose interiority is no longer of great concern and who serve, within the social relations of credit, primarily as a pass-thru or gateway to assets to be seized.

The readying of this social environment and the armed force necessary to sustain it can be described as the new security logic of credit. To take one potential example among many: Ana Carla A. Costa and Joao M. P. De Mello in "Judicial Risk and Credit Market Performance: Micro Evidence from Brazilian Payroll Loans" (2006) present the argument for the necessity of this new environment:

In recent years, the literature has built a near consensus that 'sound' institutions are congenial to good economic performance (North 1994). Institutions, insofar as they determine the economic environment agents operate in, should be important for explaining economic outcomes. Quite often, the specific mechanism through which institutions influence economic performance is protection from expropriation. In environments in which expropriation is likely, agents underinvest (from a social perspective) relative to more secure ones. In the end, a plethora of suboptimal micro-economic decisions amount to a poorer aggregate economic performance. (156)

The environment that must be created then is one in which lenders are protected "from expropriation." The legal framework of repossession and bankruptcy was the subject of a great deal of change in the early 2000s in Brazil: repossession was facilitated, bankruptcy made less complicated and certain kinds of creditors given priority over others, and crédito consignado's practice of using future income as collateral was 
defended by the state in court (Ferreira 2008: 13). ${ }^{14}$ The central aim of these changes was making the repossession and resell of assets easier and this was done, primarily, by removing rights and legal remedies from debtors. Before these changes, the general legal framework governing the repossession of collateral was that creditors could repossess but could not resell until debtors had exhausted a series of legal and juridical measures.

The argument advanced by policy makers and bankers was that making repossession easier and allowing payments to be deducted directly from individuals' income (which we might call by the less uplifting term of wage or income garnishment) would allow lenders to deepen credit markets by lending to more risky individuals. This type of argument is laid out in detail in Juliano Assunção, Efraim Benmelech, and Fernando S. S. Silva's "Repossession and the Democratization of Credit" (2013). The authors analyze the changes to repossession law and the market for auto loans, echoing a theoretical stance that proliferated throughout the mainstream economic literature and popular media in these years, that changing the nature of "property" by making it more available to seizure was in fact a form of "democratization," understood as increasing access to the equality of consumption offered by credit. As they write:

Our evidence suggests that the legal change has led to larger loans with lower spreads, longer maturities, and higher leverage. It has also brought about a "democratization" of credit, enabling riskier, lowincome borrowers to obtain loans and purchase newer, more expensive cars. Although the credit reform has improved access to credit by

\footnotetext{
${ }^{14}$ Going into the specifics of these different legal histories would take us too far afield here. For auto loans see Assunção, Benmelech, and Silva (2013); for housing see Sanfelici (2013); for consignado see De Mello and Garcia (2012); and for the hierarchy of creditors in bankruptcy see Araujo, Ferreira, and Funchal (2012).
} 
expanding credit to riskier borrowers, it has also led to increased incidences of default and repossession. In sum, this article provides evidence on the consequences of a credit reform, highlighting the crucial role that collateral plays in credit markets. (19)

These kinds of changes in repossession and bankruptcy laws reframed both the importance of private property and the legal understanding of ownership. Generally speaking, property becomes much less "private," much more fungible and easier to seize, and the importance of repossession as something fundamental to upholding the existing social order becomes much more pronounced. If credit forms a part of the postdictatorship process of democratization, and a key part of extending credit is the easy repossession and the direct seizure of income which drives profits up, then the state and para-state agencies who enforce these laws have a mandate to effect seizures using whatever means necessary. Property, the more it becomes discursively associated with democracy, becomes increasingly sacred - to the extent that upholding property rights becomes a part of upholding the very institutions of democracy.

Thus, my argument is that the legal environment that undergirds the expansion of personal credit in Brazil has required a new imbrication between the threat of state or state sanctioned violence and the production of subjects. The subjects produced in this moment, who we might call "anti-subjects" due to how their production breaks with the Christian pastoral tradition of monitoring interiority, are exposed in new ways to the threat or possibility of state violence, both because credit is inherently an unstable corporativist formation (thus leading to the use of state violence as a supplement) and because the state commits itself to defending a new, more rigid conception of private property as well as to using force to seize assets as the credit bubble expands and contracts and then deflates. 


\section{UPPs, the Caveirão of Finance}

What I have tried to trace in this article are the unexpected ways finance, public security, and state violence have accompanied one another in contemporary Brazil. Credit expansion as a form of financial corporativism has mirrored the expansion of militarized public security (Amar 2013), but also calls upon the threat of state sanctioned violence to structure its legal environment. This imbrication between attempted finance-led accumulation and state violence as joined forms of public security is nowhere more apparent than in Rio de Janeiro, in particular in its most recent public security strategy of the Unidades de Polícia Pacificadora (UPPs). ${ }^{15}$ Because Rio is in this sense an advanced laboratory of national public security strategies, I want to conclude by examining the links between finance and the UPPs and the recent appearance of new formations on the Rio political scene.

Without too much exaggeration we can see the UPPs as the caveirão of finance, opening new terrain for the more efficient extraction of financial rent and strengthening the connection between finance and state violence. This connection was visible in the first implantation of a UPP in Santa Marta, where on the morning of December 19, 2008, residents awoke to two important changes: first, the UPP and, second, many residents found tacked to their front doors an electric bill (Renato Cosentino, pers. comm.). As many commentators have noted, the UPPs have had the effect of making certain communities seem safe enough for capital to enter. However, what has not been so

\footnotetext{
${ }^{15} \mathrm{My}$ focus here on technologies of punishment and economic modes of incorporation and exploitation parallels the arguments of Loï Wacquant in Punishing the Poor: The Neoliberal Government of Social Insecurity (Duke UP, 2009). Wacquant's account is focused, however, on a shift between welfare state policies that were focused on discipline (i.e., internalization of norms by subjects) to a punitive state in which the aim is the direct punishment of marginal sectors. The account given here concerning Brazil has a punitive focus, but the extension of credit is seen, not as punitive or disciplinary gesture, but rather as a corporativist one.
}

RRASILIANA- Journal for Brazilian Studies. Vol. 4, n.2 (2016). ISSN 2245-4373. 
frequently remarked is how the UPPs open these areas to forms of financial accumulation as well. In addition to the regularization of electric, cable, and water bills (bills on which people can get "behind" and, as a result, be forced to pay "fees" which are a form of interest on past due accounts), the UPPs have brought an expansion of both banks and commercial stores into comunidades - as well as real estate speculation. While it will be obvious that banks make their money from interest and fees charged to consumers, what is perhaps less known is that as much as $20 \%$ of many stores' bottom lines are accounted for by offering credit to consumers (Saltorato and Donadone 2012). ${ }^{16}$ Thus, UPPs make possible not just the spread of commercialization or commodification (as some accounts have it), but the spread and further penetration of forms of financial accumulation into peripheral communities. ${ }^{17}$

While there is no credit data specific to Rio that differentiates between the formal city and comunidades, one can extrapolate from national data and from data on peripheral regions in São Paulo to see how credit expansion has made more vulnerable certain populations, further exposing them to the threat of violence. First, on a national level, Serasa's 2014 "Mapa da Inadimplência no Brasil," revealed the populations currently with problems managing their credit are the urban poor: with $23 \%$ of "Jovens Adultos da Periferia" and 17\% of "Massa Trabalhadora Urbana" having one credit account in default by 30 to 90 days (Serasa 2014). A 2015 Serasa study in São Paulo found that in Paraisópolis, one in three "moradores da comunidade" have a delinquent account (Serasa 2015). While a 2015 Data Favela study revealed that " $48 \%$ [of

\footnotetext{
${ }^{16}$ Saltorato and Donadone (2012) also note that financial side of large varejistas is growing much more quickly than the retail side and that the profit margins on financial services (while varying across year and establishment) are frequently twice that of retail (approaching a 100\% margin in some cases).

${ }^{17}$ It is no surprise then that the UPP project attracted the attention of the quintessential Brazilian (failed) financialized capitalist, Eike Batista (Werneck 2014), who before the collapse of his empire pledged R $\$ 20$ million per year for the UPPs.
} 
moradores] disseram ter usado o cartão de crédito emprestado de parentes ou amigos" and a 2014 study found that three out of four people who loan their names (so family members or friends can take out credit because they are unable) have delinquent accounts (Brasileiros 2015; Instituto GEOC 2014).

We can draw two perhaps obvious conclusions from this: adults in peripheral communities are the group with the greatest need for credit to fill in what their wages are unable to provide. They are also the group with the smallest margin of error when it comes to paying money back - which is illustrated by the higher rates of delinquency in comunidades. A few missed weeks of work or a lost job and individuals can become stuck, if they were not before, on a treadmill or under a mountain of unpayable debt. Second, as the economy continues to contract these will be the first people thrown out of work, which thus makes them among the most vulnerable to forms of economic decision-making that will affect their ability for self-reproduction, such as having to decide to pay their debt or rent, buy food or pay debt, etc. What is perhaps less obvious is that credit exacerbates the most marginalized individuals' already significant vulnerability. So much of the current mediatic and institutional discourse around credit in Brazil sees it as a net positive, as opposed to being what it is: a form of financial exploitation. Annual interest rates, as noted before, on credit card debt are currently topping out at $345 \%$ and are continuing to rise (Martello 2015). In a situation in which the state has already begun to take measures to decrease the credit supply and in which more and more individuals are falling behind on payments, it will become harder and harder for individuals to avoid default by rolling over or transferring their debt. As time (and credit) run out on finance as a corporativist measure, the only lever left at the state's disposal to enforce debts and keep the financial extraction running that Brazil is now dependent on is violence-and this is a purpose that new security measures like the UPPs will serve. 
I want to end, however, on a less dire note, because if finance has produced, across the territorial space of the nation and the city, new, failing forms of financial corporativism, it has also then produced, as well, new political possibilities. Several observers of Rio have noted a recent shift in political formations in the city, with new overlaps between the morro and asphalto and new alliances between comunidades, which have been attributed, in part, to the attention the UPPs have received as part of Rio's security strategy in the run up to the megaevents of the Copa and the Olympics (Bianchi 2013; Parkin 2015). That is most certainly the case, but I also would argue that at least some of the possibility for such relations is contained in the spread of linked forms of finance and state violence charted in this essay.

There are two ways in which this might be the case, and both turn on how finance, in particular in the form of credit and as real estate speculation, creates new forms of possible commonality across the formal/informal city divide. ${ }^{18}$ First, if the morro/asphalto divide has been structured in part by a divide between access to formal and informal labor markets, credit is a form of exploitation which all groups share in common. Moreover, as the air begins to slowly leak from the credit bubble and as real estate speculation continues to price people out of consolidated comunidades, a shared sense of exasperation with the state's promotion of credit as a form of democracy, and the illusory nature of this credit democracy, is apparent across social sectors - which I think is one lesson we can take from the protests of June 2013. Second, instead of seeing the UPPs as normalizing policing across the formal/informal city divide (a claim that appears difficult to make as their shine begins to wear off), we can see that attempted financial accumulation requires the spread of exceptional forms of state violence to

\footnotetext{
${ }^{18}$ I use this conceptual pair here as a heuristic only, conscious of the critique elaborated in the work of Ananya Roy and Nezar Alsayyed (2004).
} 
populations outside comunidades. ${ }^{19}$ Due to the legal redefinition of private property, the state now has to defend private property much more strenuously and at higher cost. As well, the instability of credit as a corporativist structure means that the state has to rely more on the lever of violence to control unruly populations, particularly as the credit bubble begins to deflate, if not burst. The end result is instead of Rio's future being the spread of normalized police functions to peripheral areas, it might be, in fact, more marked the reverse: the increasing exposure of multiple sectors of the population to routinized exceptional state violence.

Thus, instead of the UPPs themselves representing the beginning of a new political conjuncture as they introduce a new kind of policing into peripheral spaces, perhaps part, but only part, of the new conjecture-and the new forms of crosscommunity political contact that are emerging - is defined by the spreading of forms of financial exploitation and exceptional state violence across the urban territory. In Rio's case, perhaps there are new opportunities now for alliance-sure to be fraught and complicated-as financial exploitation has bridged different urban spaces (between morro and asphalto and between comunidades). At same time, perhaps the exceptionality of the violence of the UPPs is now more visible to traditionally middle class sectors of the city, because these sectors of the population are now exposed, in limited ways as well, to the threat of similar kinds of violence. Perhaps, then, some of the political possibilities in Rio in the financialized present are a result of the fact that instead of the povo descending the morro, the state has.

\section{References}

\footnotetext{
${ }^{19}$ In no way are the forms of violence or levels of exposure between the informal and formal city equal. I am rather pointing just to a possible basis for the recognition of the existence of such state violence, not to isomorphic situations.
}

3RASILIANA- Journal for Brazilian Studies. Vol. 4, n.2 (2016). ISSN 2245-4373. 
Alberto, Paulina. 2011. Terms of Inclusion: Black Intellectuals in Twentieth-Century Brazil. Raleigh: University of North Carolina Press.

Amar, Paul. 2013. The Security Archipelago: Human-Security States, Sexuality Politics, and the End of Neoliberalism. Durham: Duke University Press.

Araujo, Aloisio P., Rafael V.X. Ferreira, and Bruno Funchal. 2012. "The Brazilian Bankruptcy Law Experience." Journal of Corporate Finance 18(4): 994-1004.

Associação Brasileira de Empresas de Pesquisa. 2003. "Critério de Classificação Econômica Brasil." Accessed July 23, 2015. http://www.abep.org/criterio-brasil

Associated Press. 2015. "Amid Brazil's Economic Crisis, Consumers Struggle With Debt." June 15. Accessed July 19, 2015. http://nyti.ms/1TmTFKz

Assunção, Juliano, Efraim Benmelech, and Fernando S. S. Silva. 2013. "Repossession and the Democratization of Credit." Review of Financial Studies. Accessed July 23, 2015. doi: 10.1093/rfs/hht080

Antunes, Ricardo. 2004. "A trajetória (e a tragédia) do PT." Folha de S.Paulo. April 11. Accessed July 26, 2015. http://www1.folha.uol.com.br/fsp/opiniao/fz1104200409.htm

Balthazar, Camila. 2014. “Vem Reforma Política Pela Frente?” Credit Performance, December. Accessed July 19, 2015. http://www.creditperformance.com.br/web/creditperformance-marco-2014-2/

Banco Central do Brasil. n. d. "Séries Temporais." Accessed July 25, 2015. http://www4.bcb.gov.br/pec/series/port/aviso.asp

Banco Central do Brasil. 2003. "Relatório de Economia Bancária e Crédito." Accessed July 19, 2015. http://www.bcb.gov.br/?SPREADG4ANO

Banco Central do Brasil. 2015a. "Política Monetária e Operações de Crédito do SFN, Nota para a Imprensa." June 23. Accessed July 19, 2015. http://www.bcb.gov.br/?ECOIMPOM

Banco Central do Brasil. 2015b. "Relatório de Estabilidade Financiera." March. Accessed July 19, 2015. http://www.bcb.gov.br/?RELESTAB201503 
Banco Central do Brasil. 2015c. "Taxas de juros por instituição financeira." Accessed July 25, $2015.2 \quad$ http://www.bcb.gov.br/pt$\mathrm{br} / \mathrm{sfn} /$ infopban/txcred/txjuros/Paginas/RelTxJuros.aspx?tipoPessoa=1\&modalidade=220 \&encargo $=101$

Bensusán, Graciela and Marisa von Bülow. 1998. "La reforma institucional del corporativismo sindical: las experiencias de Brasil y México." Perfiles Latinoamericanos 11: 185-229.

Bianchi, Paula. 2013. "Antigas rivais, favelas da Rocinha e Vidigal realizam protesto conjunto no Rio." Uol. June 25. Accessed July 24, 2015. http://noticias.uol.com.br/cotidiano/ultimas-noticias/2013/06/25/antigas-rivais-favelasda-rocinha-e-vidigal-realizam-protesto-conjunto-no-rio.htm

Boito Jr., Armando. 1999. Política neoliberal e sindicalismo no Brasil. São Paulo : Xamã.

Brandão, Ignácio de Loyola. 1983. Zero. New York: Avon Books.

Brasileiros. 2015. "Há espaço para bancos crescerem na favela." March 3. Accessed July 19, 2015. http://brasileiros.com.br/2015/03/ha-espaco-para-bancos-crescerem-na-favela/

Chaui, Marilena. 2013. Talk at presentation of "10 anos de governos pós neoliberais no Brasil." Accessed July 23, 2015. https://www.youtube.com/watch?v=FeP4rWe0zdw Cheias de Charme. 2012. O Globo.

CNC. 2015. "Pesquisa Nacional de Endividamento e Inadimplência do Consumidor (Peic) - julho 2015." Accessed July 25, 2015. http://www.cnc.org.br/central-doconhecimento/pesquisas/economia/pesquisa-nacional-de-endividamento-einadimplencia-do-c-8

Coelho, Christiano A., João M. P. De Mello, and Bruno Funchal. 2012. "The Brazilian Payroll Lending Experiment." The Review of Economics and Statistics 94(4): 925-934.

Costa, Ana Carla A. and João M. P. De Mello. 2006. "Judicial Risk and Credit Market Performance: Micro Evidence from Brazilian Payroll Loans." NBER Working Paper No. 12252. Accessed July 23, 2015. http://www.nber.org/papers/w12252

De Mello, João Manoel P. and Márcio G.P. Garcia. 2012. “Bye, bye financial repression, 
hello financial deepening: The anatomy of a financial boom." The Quarterly Review of Economics and Finance 52(2): 135-53.

Diário da Manhã. 2015. “Moradores de favelas movimentam R\$ 68,6 bilhões por ano, mostra estudo." March 2. Accessed July 19, 2015. http://www.dm.com.br/economia/2015/03/moradores-de-favelas-movimentam-r-686bilhoes-por-ano-mostra-estudo.html

Federal Reserve. 2015. "Household Debt Service and Financial Obligations Ratios." Accessed July 25, 2015. http://www.federalreserve.gov/releases/housedebt/

Ferreira, Flávio, Matheus Leitão and Andréia Sadi. 2012. "Procuradoria vai recorrer da extinção de ação contra Lula." Folha. Accessed July 20, 2015. http://www1.folha.uol.com.br/poder/2012/11/1188467-procuradoria-vai-recorrer-daextincao-de-acao-contra-lula.shtml

Ferreira, Isabel Cristina. 2008. "Crédito consignado e superendividamento." Trabalho de Conclusão de Curso, Faculdade de Direito da Pontifícia Universidade Católica do Rio Grande do Sul. Porto Alegre: PUC. Accessed July 23, 2015. http://www3.pucrs.br/pucrs/files/uni/poa/direito/graduacao/tcc/tcc2/trabalhos2008_1/isa bel_cristina.pdf

Foucault, Michel. 1979. Discipline and Punish: The Birth of the Prison. Alan Sheridan, trans. New York: Vintage Books. . 1982. “The Subject and Power." Critical Inquiry 8(4): 777-795.

Gigliucci, Paulo. 2011. Crédito consignado a aposentados e pensionistas do INSS. Accessed July 20, 2015. http://www.teses.usp.br/teses/disponiveis/12/12138/tde-29032012183533/en.php

Grijó, Wesley Pereira. 2014. “De Voyeur a Protagonista: Nova classe média e telenovelas no Brasil." Estudos em Comunicação 17: 191-212.

Grün, Roberto. 2004. “A Evolução Recente do Espaço Financeiro no Brasil e Alguns Reflexos na Cena Política." DADOS, Revista de Ciências Sociais 47(1): 5-47.

Grün, Roberto. 2005. “O ‘Nó’ dos fundos de pensão.” Novos Estudos 73: 19-31. 
Grün, Roberto. 2009. "Financeirização de esquerda?" Tempo Social, revista de sociologia da USP 21(2): 255-297.

Instituto GEOC. 2014. “41,16\% dos brasileiros sentiram no bolso a recessão econômica em 2014." Press release.

Jardim, Maria A. Chaves. 2007. Entre a Solidariedade e o Risco: Sindicatos e Fundos de Pensão em Tempos de Governo Lula. Tese de doutorado, UFSCar, São Carlos. Accessed July 25, 2015.

http://www.bdtd.ufscar.br/htdocs/tedeSimplificado/tde_busca/processaArquivo.php?cod Arquivo $=1756$

Joseph, Tiffany. 2013. "How does racial democracy exist in Brazil?" Ethnic and Racial Studies 36(10): 1524-1543.

Lazzarato, Maurizio. 2012. The Making of Indebted Man: An Essay on the Neoliberal Condition. Los Angeles: Semiotext(e).

Levin, Johnathan. 2015. "Debt Collection Companies on Rise Shows How Far Brazil Has Sunk." Bloomberg. June 17. Accessed July 23, 2015. http://www.bloomberg.com/news/articles/2015-06-18/debt-collection-companies-on-riseshows-how-far-brazil-has-sunk

Martello, Alexandro. 2007. "Volume de crédito dos bancos atinge R\$ 900 bilhões em novembro." Globo G1. December 26. Accessed July 26, 2015. http://g1.globo.com/Noticias/Economia_Negocios/0,,MUL239088-9356,00VOLUME+DE+CREDITO+DOS+BANCOS+ATINGE+R+BILHOES+EM+NOVEMBRO.ht $\mathrm{ml}$

2015. "Juro do cheque especial é o maior em quase 20 anos e do cartão vai a 345\%." Globo G1. April 24. Accessed July 19, 2015. http://g1.globo.com/economia/seudinheiro/noticia/2015/04/juro-do-cheque-especial-e-o-maior-em-quase-20-anos-e-docartao-soma-345.html

Mauro, Rosana and Eneus Trindade. 2012. "Telenovela e discurso como mudança social na análise da personagem Maria da Penha em Cheias de Charme." Em questão 18(2): 169182.

3RASILIANA- Journal for Brazilian Studies. Vol. 4, n.2 (2016). ISSN 2245-4373. 
Moreira, Ivana. 2005. "BMG é o pioneiro no crédito consignado." Valor Econômico. July 5, A4.

Müller, Lúcia. 2014. "Negotiating debts and gifts: Financialization policies and the economic experiences of low-income social groups in Brazil." Vibrant 11(1): 191-221.

Nascimento, Iolanda. 2008. "Banco do Brasil compra carteiras de consignado." Gazeta Mercantil. October 10.

Neri, Marcelo Côrtes. 2008. A Nova Classe Média: O Lado Brilhante dos Pobres. Rio de Janeiro: Fundação Getulio Vargas.

Oliveira, Janaína. 2015. “Empréstimo consignado dispara na crise.” Hoje em dia. May 17. Accessed July 19, 2015. http://www.hojeemdia.com.br/noticias/economia-enegocios/emprestimo-consignado-dispara-na-crise-1.318637

Pacheco, Filipe and Ney Hayashi Cruz. 2015. "Brazil in Crisis Means 93 Company Downgrades Just the Beginning." Bloomberg. July 19. Accessed July 23, 2015. http://www.bloomberg.com/news/articles/2015-07-19/brazil-in-crisis-means-93company-downgrades-just-the-beginning

Parkin, Brooke. 2015. “Anti-Eviction Activist Wins Election in Indiana Favela." Accessed July 24, 2015. http://www.rioonwatch.org/?p=23098

Pochmann, Marcio. 2014. O mito da grande classe média: capitalismo e estructura social. São Paulo: Biotempo.

Recondo, Felipe, Fausto Macedo and Alana Rizzo. 2012. "Valério acusa Luiz Marinho de beneficiar BMG." O Estado de S. Paulo. December 11. Accessed July 20, 2015. http://politica.estadao.com.br/noticias/geral,valerio-acusa-luiz-marinho-de-beneficiarbmg,972061

Reiter, Bernd and Gladys L. Mitchell, eds. 2010. Brazil's New Racial Politics. Boulder, CO: Lynne Rienner.

Rodrigues, Azelma. 2003. “Bancos devem liberar até R\$ 160 bi em crédito consignado, diz Palocci." Valor Econômico. October 24. http://www.valor.com.br/arquivo/385821/bancosdevem-liberar-ate-r-160-bi-em-credito-consignado-diz-palocci 
Roy, Ananya and Nezar Alsayyed, eds. 2004. Informality: Transnational Perspectives from the Middle East, Latin America, and South Asia. Lanham, MD: Lexington Books.

Salomon, Marta. 2006. "Procuradoria investigará se Lula beneficiou o BMG." Folha. May 1. Accessed July 20, 2015. http://www1.folha.uol.com.br/fsp/brasil/fc0105200602.htm

Saltorato, Patrícia and Júlio César Donadone. 2012. “Banqueiros e bancários na construção do varejo financeiro nacional." Accessed July 19, 2015. http://portal.anpocs.org/portal/index.php?option=com_docman\&task=doc_details\&gid= 8024\&Itemid=217

Sanfelici, Daniel. 2013. "Financeirização e a produção do espaço urbano no Brasil: uma contribuição ao debate." EURE: Revista Latinoamericana de Estudios Urbano Regionales 39(118). Accessed July 24, 2015. http://dx.doi.org/10.4067/S0250-71612013000300002

Serasa. 2014. "Mapa da Inadimplência no Brasil." Accessed July 19, 2015. http://www.serasaexperian.com.br/estudo-inadimplencia/

Serasa. 2015. "Um em cada três moradores da comunidade de Paraisópolis, em São Paulo, está inadimplente." January 6. Accessed July 19, 2015. http://www.serasaconsumidor.com.br/um-em-cada-tres-moradores-da-comunidade-deparaisopolis-em-sao-paulo-esta-inadimplente-revela-estudo-inedito-da-serasa/

Souza, Jessé. 2012. Os Batalhadores. Belo Horizonte: Editora UFMG.

SPC. 2015a. " $84 \%$ dos consumidores que não possuem conta corrente fazem compras parceladas." Accessed July 19, 2015. https://spcbrasil.org.br/imprensa/pesquisas/76784dosconsumidoresquenaopossuemcontacorrentefazemcomprasparceladas

SPC. 2015b. "Inadimplência aumenta 4,60\% no primeiro semestre, mostra indicador SPC Brasil." Accessed July 19, 2015. https://www.spcbrasil.org.br/imprensa/indices/136inadimplenciaaumenta460noprimeirosemestremostraindicadorspcbrasil

Telles, Edward. 2014. Pigmentocracies: Ethnicity, Race and Color in Latin America. Raleigh: University of North Carolina Press.

The Economist. 2015. "Brazil's Coming Recession: The crash of a titan." February 28. Accessed July 19, 2015. http://www.economist.com/news/finance-and- 
economics/21645248-brazils-fiscal-and-monetary-levers-are-jammed-result-it-risksgetting-stuck

Veloso, Leticia. 2012. "Child Street Labor in Brazil: Licit and Illicit Economies in the Eyes of Marginalized Youth." The South Atlantic Quarterly 111(4): 663-679.

Vozes da Nova Classe Média (Cuaderno 4). 2013. Accessed July 19, 2015. http://www.sae.gov.br/documentos/publicacoes/vozes-da-nova-classe-media\%E2\%80\%93-3\%C2\%BA-caderno/

Watts, Johnathan. 2013. "Brazil's bolsa familia scheme marks a decade of pioneering poverty relief." The Guardian. December 17. Accessed July 23, 2015. http://www.theguardian.com/global-development/2013/dec/17/brazil-bolsa-familiadecade-anniversary-poverty-relief

Weissheimer, Marco Aurélio. 2004. "Lula defende política econômica, mas admite problema com juros." Carta Maior. April 29. Accessed July 20, 2015. http:/cartamaior.com.br/?/Editoria/Politica/Lula-defende-politica-economica-masadmite-problema-com-juros/4/2811

Werneck, Felipe. 2010. “Eike Batista promete R \$ 100 milhões para reforçar segurança do Rio até 2014." O Estado de S. Paulo. August 24. Accessed July 23, 2015. http://brasil.estadao.com.br/noticias/geral,eike-batista-promete-r-100-milhoes-para-reforcarseguranca-do-rio-ate-2014,599769

Wiarda, Howard J. ed. 2004. Authoritarianism and Corporatism in Latin America-Revisited. Gainesville, FL: University of Florida Press.

Zaverucha, Jorge. 2005. FHC, forças armadas e polícia: entre o autoritarismo e a democracia, 1999-2002. Rio de Janeiro: Editora Record. 